\title{
Relationships between Plant Species Richness and Environmental Factors in Nature Reserves at Different Spatial Scales
}

\author{
Xiuhua Zhang ${ }^{1,2}$, Hui Wang ${ }^{1}$, Renqing Wang ${ }^{1,3,4}$, Yutao Wang ${ }^{4}$, Jian Liu ${ }^{1^{*}}$ \\ ${ }^{1}$ Institute of Environmental Research, Shandong University, Jinan 250100, China \\ ${ }^{2}$ Shandong Urban Construction Vocational College, Jinan 250103, China \\ ${ }^{3}$ Institute of Ecology and Biodiversity, School of Life Sciences, \\ Shandong University, Jinan 250100, China \\ ${ }^{4}$ Shandong Provincial Engineering and Technology Research Center for Vegetation Ecology, \\ Shandong University, Jinan 250100, China
}

Received: 18 November 2016

Accepted: 16 February 2017

\begin{abstract}
The relationships between species richness and driving factors might vary with taxa and spatial scale. For this study we used plant species data of eight groups from nature reserves in China, namely pteridophytes, gymnosperms, angiosperms, vascular plants, Chinese endemic species, rare and endangered plants, woody plants, and herbaceous plants, and eight putative environmental predictors to explore the relationships between plant species richness and environmental factors at two spatial scales (temperate region and national scale). Our data suggested that area, mean annual temperature, and mean annual precipitation were the determinants of variation in species richness within these eight groups in the temperate nature reserves of Shandong Province in China. The relationships between plant species richness and environmental factors were consistent in different groups. However, the relationships between species richness and mean annual temperature varied with spatial scale. In the temperate region, species richness was negatively correlated with mean annual temperature and positively correlated with mean annual precipitation, whereas on a national scale species richness was positively correlated with both mean annual temperature and mean annual precipitation. Our study confirmed that the relationships between plant species richness and environmental factors in nature reserves were consistent in the studied groups and varied with spatial scale.
\end{abstract}

Keywords: nature reserves, biodiversity, plant groups, environmental factors

\section{Introduction}

Species richness is distributed heterogeneously across the Earth's surface [1], diminishing from the equator to

*e-mail: ecology@sdu.edu.cn polar regions [2]. For more than two centuries, ecologists have been trying to explain the factors that determine species richness patterns in various groups across the globe. These studies include species richness patterns of birds [3-4], mammals [5], vascular plants [6], woody plants [2, 7-8], and seed plants [9-10]. In general, it is widely accepted that species richness is related to various 
factors, such as area [11-13], climate [6,10], and landscape heterogeneity [10-11].

Over the past decades, ecologists have come to realize that species richness patterns are scale-dependent $[12,14-$ 17]. An increasing number of studies have documented that water availability, energy availability, and habitat heterogeneity are often regarded as three broad categories of environmental factors that determine broad-scale species richness variation $[1,10,16,18]$; the energy variables are divided into ambient energy and productive energy [19]. Although researchers have made great efforts to understand factors that determine the variation in species richness with taxa and spatial scale, they have not reached a consensus on which environmental factors are primary drivers of the variation in species richness. Therefore, further research is needed to understand the factors that determine species richness of different plant groups at different spatial scales in order to provide a more complete picture of diversity distribution and its determinants.

In addition, a nature reserve is a key area for conserving biodiversity and sustaining considerable diversity of species richness [20]. A nature reserve is suitable for studying the relationship between plant species richness and environmental factors because of its high biodiversity and little anthropogenic impact. Understanding the relationship between species richness and the environmental factors is very important to protect biodiversity efficiently.

Previous research on species richness patterns was mainly focused on vascular plants or a group of plants (i.e., woody or herbaceous plants), and few of the studies investigated endemic, rare, and endangered plants. In this study, using plant species data of eight groups (pteridophytes, gymnosperms, angiosperms, vascular plants, Chinese endemic species, rare and endangered plants, woody plants, and herbaceous plants) from 23 nature reserves within the temperate region (Shandong Province, China) and eight putative environmental predictors (area, mean annual temperature, mean temperature of the coldest month, mean temperature of the hottest month, hours of sunshine, frost-free days, mean annual precipitation, and elevation range), we aim to:

1. Identify the main factors determining species richness in temperate nature reserves of Shandong Province in China.

2. Determine whether the relationships between plant species richness and environmental factors are consistent within examined groups.

3. Explore the relationship between species richness and environmental factors in a temperate region.

4. Using species richness of five groups (pteridophytes, gymnosperms, angiosperms, vascular plants, and rare and endangered plants) in 186 nature reserves across China, we aim to indicate major environmental factors influencing species richness on a national scale and to test whether the relationships between species richness and environmental factors on the national scale are consistent within the five groups. Finally, we attempt to answer the question whether the relationship between the main explanatory factors and species richness of the groups varies with spatial scales.

\section{Methods}

\section{Data Collection}

Data on species richness of eight groups (pteridophytes, gymnosperms, angiosperms, vascular plants, Chinese endemic species, rare and endangered plants, woody plants, and herbaceous plants) in 23 nature reserves across the temperate region in Shandong Province (Fig. 1, Table 1) and five groups (pteridophytes, gymnosperms, angiosperms, vascular plants, and rare and endangered plants) from 163 nature reserves in other regions of China were collected (in total 186 nature reserves; Fig. 2 , Table 1), covering a total area of $70,866.73 \mathrm{~km}^{2}$. These nature reserves are located between the latitudes of $18^{\circ} 48^{\prime}$ $53^{\circ} 61^{\prime} \mathrm{N}$ and the longitudes of $82^{\circ} 48^{\prime}-129^{\circ} 48^{\prime} \mathrm{E}$. Data on species richness for the eight groups in 23 nature reserves across Shandong Province were obtained mainly from comprehensive observation reports, species checklists, and monographs about the nature reserves [21-23]. Species richness data of the 163 nature reserves were mainly obtained from published and unpublished literature and official nature reserve websites. Information on Chinese endemic species was based on three monographs [2426]. The information about rare and endangered species was determined according to the Information system of Chinese Rare and Endangered Plants (ISCREP) (rep. iplant.cn).

This study of putative predictors included eight variables: mean annual temperature (MAT), mean temperature of the coldest month (TCM), mean temperature of the hottest month (THM), and frost-free days (FFD) are measures of ambient energy; hours of sunshine (HS) is a measure of productive energy; mean annual precipitation (MAP) is a measure of water availability; and elevation range (ER), which was calculated as the difference between the maximum and minimum elevation in each nature reserve, is widely used as a surrogate of habitat

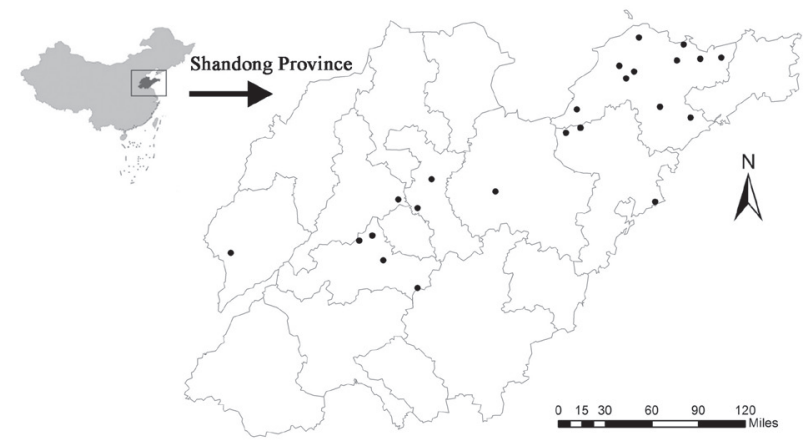

Fig. 1. Location of the 23 nature reserves across Shandong Province, China. 
Table 1. Summary statistics of plant species richness, climatic variables, nature reserve area, and topographical variability of 23 nature reserves in a temperate region of Shandong Province, and 186 nature reserves across China.

\begin{tabular}{|c|c|c|c|c|c|c|c|c|}
\hline Spatial scale & Variable & $\mathrm{N}$ & Minimum & Maximum & Mean & SD & Skewness & Kurtosis \\
\hline \multirow{22}{*}{$\begin{array}{l}\text { Temperate } \\
\text { region } \\
\text { (Shandong } \\
\text { Province) }\end{array}$} & \multicolumn{8}{|c|}{ Species richness } \\
\hline & Pteridophytes & 23 & 11 & 50 & 26.6 & 9.4 & 0.5 & 0.3 \\
\hline & Gymnosperms & 23 & 5 & 51 & 24.2 & 11.5 & 0.6 & -0.2 \\
\hline & Angiosperms & 23 & 387 & 1321 & 833.4 & 199.4 & 0.9 & 2.5 \\
\hline & Vascular plants & 23 & 403 & 1422 & 885.3 & 216.9 & 0.8 & 2.3 \\
\hline & Woody plants & 23 & 124 & 461 & 250.5 & 74.1 & 1.6 & 3.3 \\
\hline & Herbaceous plants & 23 & 286 & 970 & 639.2 & 153.8 & 0.4 & 1 \\
\hline & Chinese endemic species & 23 & 2 & 16 & 7.9 & 3.9 & 0.4 & -0.3 \\
\hline & Rare and endangered plants & 23 & 19 & 128 & 51.3 & 27 & 1.3 & 1.7 \\
\hline & & & & tion and area & & & & \\
\hline & Mean latitude $\left({ }^{\circ}\right)$ & 23 & 35.7 & 37.7 & 36.8 & 0.5 & -0.3 & -0.9 \\
\hline & Mean longitude $\left({ }^{\circ}\right)$ & 23 & 115.6 & 121.7 & 119.4 & 1.7 & -0.6 & -0.9 \\
\hline & Reserve area $\left(\mathrm{km}^{2}\right)$ & 23 & 12 & 448.55 & 101.6 & 94.9 & 2.4 & 7.7 \\
\hline & & & & atic variable & & & & \\
\hline & $\operatorname{MAT}\left({ }^{\circ} \mathrm{C}\right)$ & 23 & 9.1 & 13.9 & 12.1 & 1 & -0.8 & 3 \\
\hline & $\mathrm{TCM}\left({ }^{\circ} \mathrm{C}\right)$ & 23 & -7.7 & -0.7 & -2.7 & 2.4 & -1.9 & 4.5 \\
\hline & $\mathrm{THM}\left({ }^{\circ} \mathrm{C}\right)$ & 23 & 22 & 28 & 25.5 & 1.3 & -0.2 & 2.3 \\
\hline & MAP (mm) & 23 & 608.3 & $1,131.7$ & 778.1 & 146.1 & 1.1 & 0.7 \\
\hline & HS (h) & 23 & $2,371.2$ & 2863 & $2,628.9$ & 112.5 & 0.1 & 0.7 \\
\hline & FFD (d) & 23 & 171.8 & 223 & 198.5 & 11.8 & -0.3 & 0.5 \\
\hline & & & $\mathrm{Hab}$ & theterogene & & & & \\
\hline & $\mathrm{ER}(\mathrm{m})$ & 23 & 10 & 1400 & 595 & 293.5 & 0.6 & 2.0 \\
\hline \multirow{13}{*}{$\begin{array}{l}\text { National } \\
\text { scale } \\
\text { (China) }\end{array}$} & \multicolumn{8}{|c|}{ Species richness } \\
\hline & Pteridophytes & 146 & 1 & 297 & 106 & 79.9 & 0.6 & -0.7 \\
\hline & Gymnosperms & 138 & 3 & 52 & 18.4 & 10.2 & 0.9 & 0.6 \\
\hline & Angiosperms & 138 & 155 & 3,114 & $1,329.9$ & 605.5 & 0.5 & -0.4 \\
\hline & Vascular plants & 171 & 162 & 3,481 & $1,487.2$ & 711.6 & 0.5 & -0.4 \\
\hline & Rare and endangered plants & 54 & 5 & 193 & 54.4 & 42.4 & 1.6 & 2.6 \\
\hline & \multicolumn{8}{|c|}{ Location and area } \\
\hline & Mean latitude $\left({ }^{\circ}\right)$ & 186 & 18.8 & 53.1 & 31.9 & 7.1 & 0.7 & -0.1 \\
\hline & Mean longitude $\left({ }^{\circ}\right)$ & 186 & 82.8 & 129.8 & 113.1 & 7.2 & -0.4 & 0.9 \\
\hline & Reserve area $\left(\mathrm{km}^{2}\right)$ & 186 & 11.6 & $4,091.4$ & 381 & 603.4 & 4.1 & 20.5 \\
\hline & \multicolumn{8}{|c|}{ Climatic variables } \\
\hline & $\operatorname{MAT}\left({ }^{\circ} \mathrm{C}\right)$ & 186 & -6 & 25.3 & 12.4 & 6.1 & -0.8 & 0.5 \\
\hline & MAP (mm) & 186 & 174.7 & $3,119.5$ & $1,243.3$ & 610.8 & 0.5 & -0.4 \\
\hline
\end{tabular}

MAT $=$ mean annual temperature, $\mathrm{TCM}=$ mean temperature of the coldest month, $\mathrm{THM}=$ mean temperature of the hottest month, $\mathrm{MAP}=$ mean annual precipitation, $\mathrm{HS}=$ hours of sunshine, $\mathrm{FFD}=$ frost-free days, $\mathrm{ER}=$ elevation range, $\mathrm{N}=\mathrm{Number}$ of nature reserves, $\mathrm{SD}=$ standard deviation 


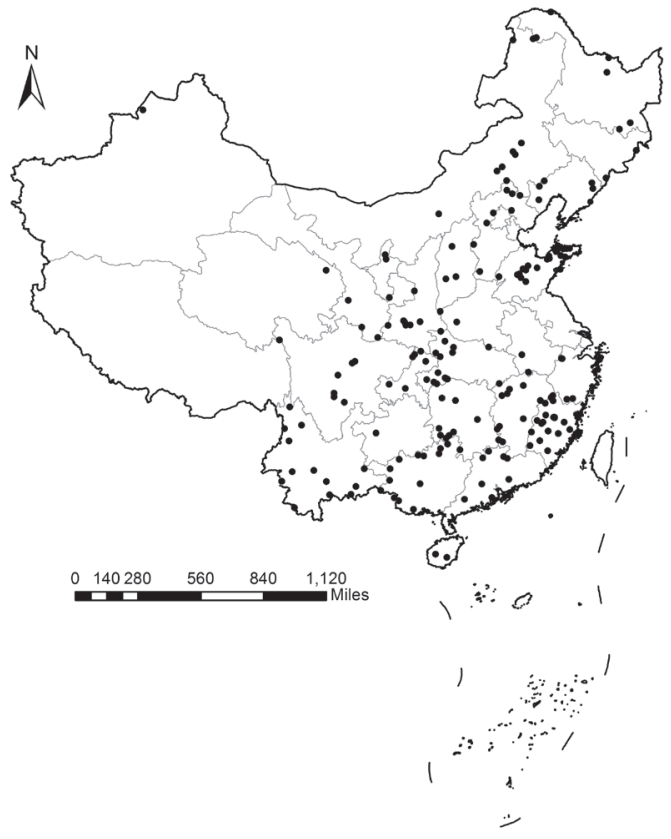

Fig. 2. Location of the 186 nature reserves across China..

heterogeneity. Data for temperature and precipitation from 1981 to 2010 were obtained from climate stations. Data for the area and elevation range of each nature reserve were obtained from official nature reserve websites and the Ministry of Environmental Protection of the People's Republic of China (zhb.gov.cn/stbh/zrbhq/qgzrbhqml/ index_1.shtml).

Table 2. Principal component analysis (PCA) of variables of the 23 studied nature reserves. Factor I reflects temperature trend, Factor II reflects area trend, and Factor III reflects precipitation trend. Higher loadings $(>|0.85|)$ are highlighted in bold.

\begin{tabular}{|c|c|c|c|}
\hline \multirow{2}{*}{$\begin{array}{c}\text { Environmental } \\
\text { predictor }\end{array}$} & \multicolumn{3}{|c|}{ PCA factors } \\
\cline { 2 - 4 } & $\begin{array}{c}\text { Factor I } \\
\text { (Temperature) }\end{array}$ & $\begin{array}{c}\text { Factor II } \\
\text { (Area) }\end{array}$ & $\begin{array}{c}\text { Factor III } \\
\text { (Precipitation) }\end{array}$ \\
\hline MAT & $\mathbf{0 . 9 0 3}$ & 0.195 & -0.008 \\
\hline TCM & 0.796 & 0.308 & -0.251 \\
\hline THM & $\mathbf{0 . 9 0 2}$ & 0.169 & -0.075 \\
\hline HS & -0.597 & -0.076 & -0.590 \\
\hline FFD & 0.381 & 0.727 & 0.162 \\
\hline MAP & -0.133 & 0.175 & $\mathbf{0 . 9 2 9}$ \\
\hline ER & -0.250 & -0.498 & 0.599 \\
\hline Area & 0.103 & $\mathbf{0 . 8 6 8}$ & -0.001 \\
\hline $\begin{array}{c}\text { Cumulative } \\
\text { variance (\%) }\end{array}$ & $\mathbf{3 5 . 6 8 5}$ & $\mathbf{5 7 . 2 9 6}$ & $\mathbf{7 8 . 1 0 3}$ \\
\hline
\end{tabular}

$\mathrm{MAT}=$ mean annual temperature, $\mathrm{TCM}=$ mean temperature of the coldest month, THM = mean temperature of the hottest month, HS = hours of sunshine, FFD = frost-free days, $\mathrm{MAP}=$ mean annual precipitation, $\mathrm{ER}=$ elevation range
Table 3. Standardized regression coefficients and coefficients of determination $\left(R^{2}\right)$ of multiple regressions for species richness, according to ordinary least squares (OLS) and simultaneous autoregressive (SAR) models.

\begin{tabular}{|c|c|c|c|c|}
\hline \multirow[b]{2}{*}{$\begin{array}{l}\text { Richness } \\
\text { variable }\end{array}$} & \multicolumn{4}{|c|}{ Predictors in the model } \\
\hline & $\begin{array}{c}\text { Mean } \\
\text { Annual } \\
\text { Temperature }\end{array}$ & Area & $\begin{array}{c}\text { Mean } \\
\text { Annual } \\
\text { Precipitation }\end{array}$ & $R^{2}$ \\
\hline \multicolumn{5}{|c|}{ pteridophytes } \\
\hline OLS & -0.276 & 0.547 & 0.301 & 0.606 \\
\hline SAR & -0.269 & 0.568 & 0.278 & 0.587 \\
\hline \multicolumn{5}{|c|}{ gymnosperms } \\
\hline OLS & -0.175 & 0.565 & 0.171 & 0.462 \\
\hline SAR & -0.225 & 0.593 & 0.152 & 0.458 \\
\hline \multicolumn{5}{|c|}{ angiosperms } \\
\hline OLS & -0.353 & 0.561 & 0.315 & 0.705 \\
\hline SAR & -0.373 & 0.631 & 0.241 & 0.698 \\
\hline \multicolumn{5}{|c|}{ vascular plants } \\
\hline OLS & -0.349 & 0.572 & 0.304 & 0.705 \\
\hline SAR & -0.368 & 0.640 & 0.236 & 0.699 \\
\hline \multicolumn{5}{|c|}{ woody plants } \\
\hline OLS & -0.383 & 0.420 & 0.333 & 0.681 \\
\hline SAR & -0.385 & 0.418 & 0.342 & 0.655 \\
\hline \multicolumn{5}{|c|}{ herbaceous plants } \\
\hline OLS & -0.257 & 0.566 & 0.246 & 0.571 \\
\hline SAR & -0.263 & 0.669 & 0.174 & 0.565 \\
\hline \multicolumn{5}{|c|}{ Chinese endemic species } \\
\hline OLS & -0.241 & 0.455 & 0.435 & 0.686 \\
\hline SAR & -0.274 & 0.492 & 0.456 & 0.688 \\
\hline \multicolumn{5}{|c|}{ rare and endangered plants } \\
\hline OLS & -0.267 & 0.662 & 0.349 & 0.821 \\
\hline SAR & -0.284 & 0.682 & 0.316 & 0.819 \\
\hline
\end{tabular}

\section{Data Analysis}

Initially, the effects of environmental variables on species richness across the temperate region (Shandong Province) were investigated through ordinary least squares (OLS) multiple regression analyses. To account for potential multicollinearity of the predictor variables, we first established the main trends of the variation through a Varimax-rotated principal component analysis (VrPCA). Through VrPCA, we captured three factors (mean annual temperature, area, and mean annual precipitation), which jointly described $78.1 \%$ of the variance. For each species richness variable, we generated an OLS multiple regression model, including the three PCA factors. Considering the 
spatial autocorrelation in the regression models, we used simultaneous autoregressive (SAR) models to compare OLS results in each multiple regression [27].

The relationships between environmental variation (mean annual temperature and mean annual precipitation) and species richness of the eight groups in 23 nature reserves across the temperate region (Shandong Province) were explored using the general linear model. To test whether the relationship between the environmental factors and species richness varies with spatial scale, we studied the correlation between two environmental variables (mean annual temperature and mean annual precipitation) and species richness of five groups (pteridophytes, gymnosperms, angiosperms, vascular plants, and rare and endangered plants) in 186 nature reserves across China.

The Spearman's rank correlations were used to determine species richness patterns among the eight groups.

All statistical analyses were performed using Statistical Package for the Social Sciences (SPSS) 19.0 (IBM Corp., Armonk, NY, USA) and Spatial Analysis in Macroecology (SAM) v4.0 (available at ecoevol.ufg.br/sam).

\section{Results}

\section{Determining Factors of Species Richness in a Temperate Region}

The principal component analysis (PCA) of variables of the 23 studied nature reserves showed that mean annual temperature, nature reserve area, and mean annual precipitation were the three determinant factors of species richness in the temperate region of Shandong Province across China (Table 2).
The simultaneous autoregressive (SAR) models for each species richness group, which incorporated spatial autocorrelation explicitly, showed that the spatial autocorrelation did not affect the standardized regression coefficients, as the relative importance and the significance of the standardized regression coefficients did not change (Table 3).

We found that OLS models explained $82.1 \%, 70.5 \%$, $70.5 \%, 68.6 \%, 68.1 \%, 60.6 \%, 57.1 \%$, and $46.2 \%$ of variation in rare and endangered plants, vascular plants, angiosperms, Chinese endemic species, woody plants, pteridophytes, herbaceous plants, and gymnosperms, respectively (Table 3). Multiple regression models provided consistent primary predictors of species richness for different groups in the temperate nature reserves, and they included the area, mean annual temperature, and mean annual precipitation (Table 3). Across all models, the effects of the area on species richness were generally greater than those of temperature and precipitation (Table 3). The temperature variable contributed more to species richness of gymnosperms, angiosperms, vascular plants, woody plants, and herbaceous plants than did precipitation, while precipitation was more important than temperature for pteridophytes, Chinese endemic species, and rare and endangered plants (Table 3).

\section{Relationships between Plant Species and Environmental Variables at Two Spatial Scales}

Across the temperate region (Shandong Province), the relationship between species richness and temperature was negative (Table 3, Fig. 3), while the relationship between precipitation and species richness was positive (Table 3, Fig. 4). The relationships between plant species richness

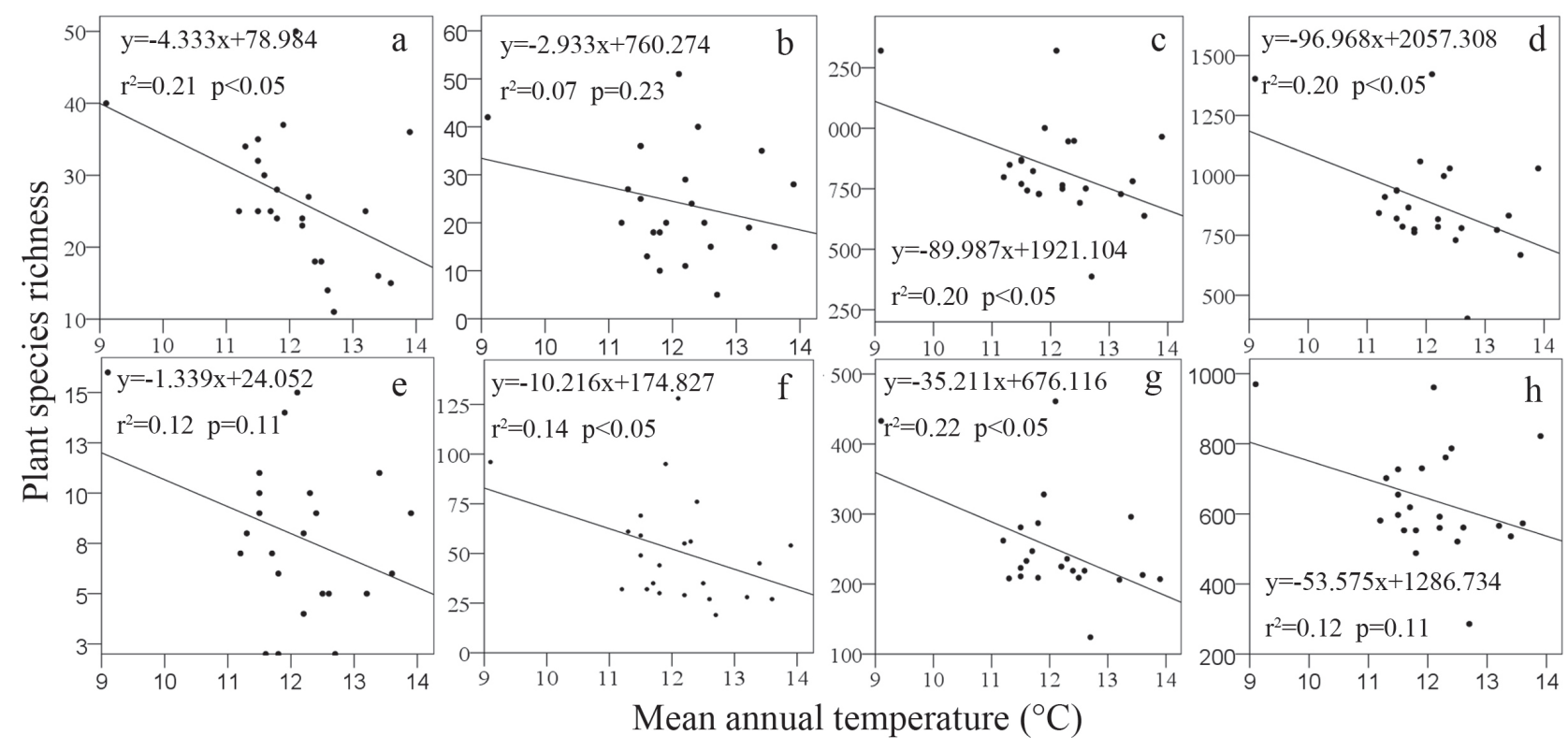

Fig. 3. Relationships between plant species richness and mean annual temperature of the 23 nature reserves across temperate region (Shandong Province). a) pteridophytes, b) gymnosperms, c) angiosperms, d) vascular plants, e) Chinese endemic species, f) rare and endangered plants, g) woody plants, h) herbaceous plants. 


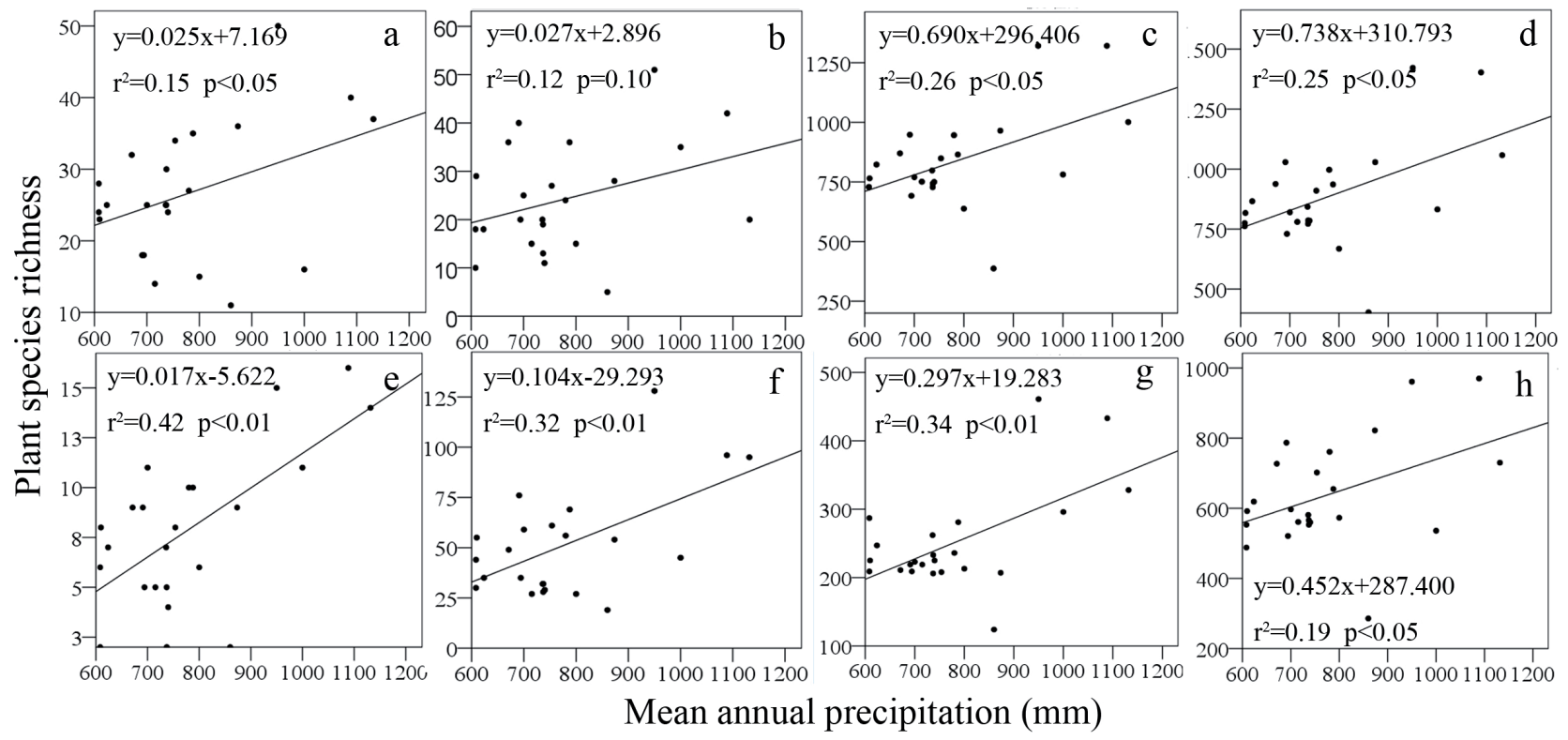

Fig. 4. Relationships between plant species richness and mean annual precipitation of the 23 nature reserves across temperate region (Shandong Province). a) pteridophytes, b) gymnosperms, c) angiosperms, d) vascular plants, e) Chinese endemic species, f) rare and endangered plants, g) woody plants, h) herbaceous plants.

and the area, mean annual temperature, and mean annual precipitation were consistent in the eight groups (Table 3, Figs 3-4).

At the national scale, the relationship between species richness of the five groups (pteridophytes, gymnosperms, angiosperms, vascular plants, and rare and endangered plants) and temperature was significant and positive (Fig. 5a-e). Precipitation positively and significantly affected the species richness of pteridophytes, angiosperms, vascular plants, and rare and endangered plants at the national scale (Figs 6a-e). The relationships between species richness and mean annual temperature and mean annual precipitation were also consistent in these five groups (Figs 5-6).

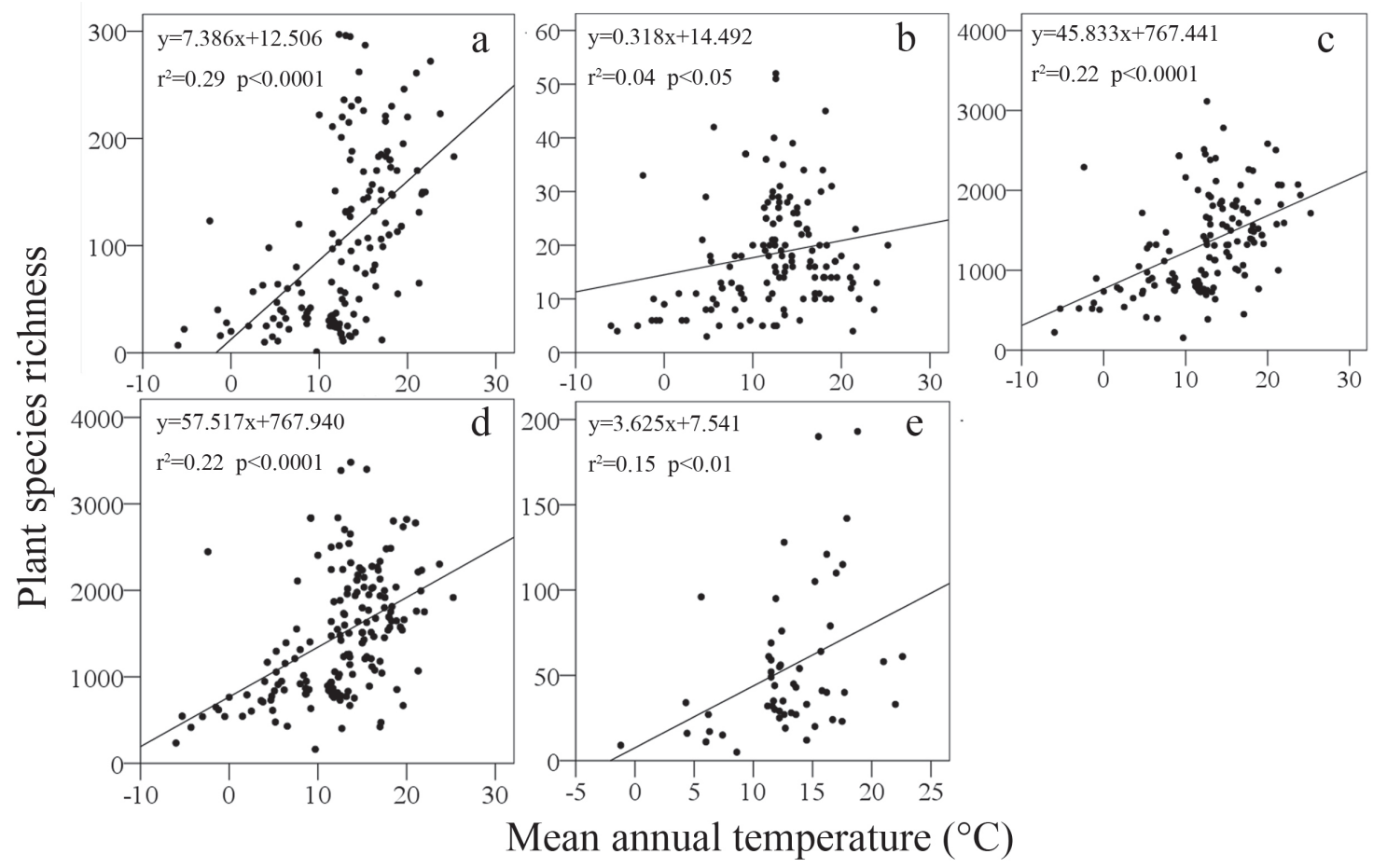

Fig. 5. Relationships between plant species richness and mean annual temperature of the 186 nature reserves across China. a) pteridophytes, b) gymnosperms, c) angiosperms, d) vascular plants, e) rare and endangered plants. 


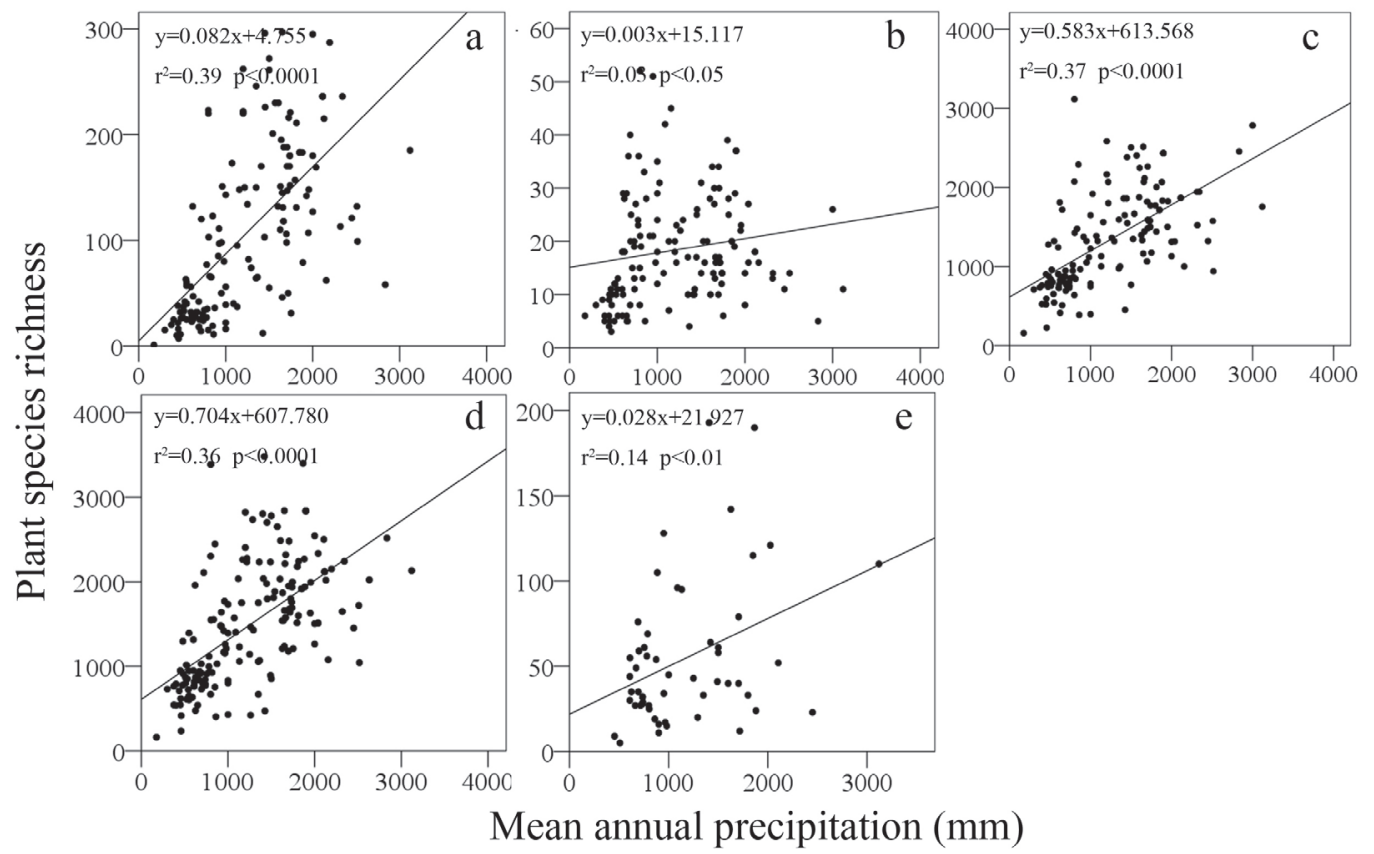

Fig. 6. Relationships between plant species richness and mean annual precipitation of the 186 nature reserves across China. a) pteridophytes, b) gymnosperms, c) angiosperms, d) vascular plants, e) rare and endangered plants.

\section{Correlation Analysis of Species Richness among Eight Groups}

Spearman's rank correlation (Table 4) showed that the correlations among species richness for all the eight groups tended to be high. The species richness of woody plants and herbaceous plants were the least congruent $(r=0.425, p<0.05)$. Chinese endemic plants and rare and endangered plants showed stronger correlations with herbaceous plants $(r=0.786, p<0.01$, and $r=0.668$, $p<0.01$, respectively) than they did with woody plants ( $r=0.637, p<0.01$, and $r=0.473, p<0.05$, respectively). Description of this sentence is different from the results of our study. So it should be changed to" The species richness of Chinese endemic plants correlated the most with species richness of gymnosperms $(r=0.875$, $p<0.01$ ), while species diversity of rare and endangered plants correlated the most with Chinese endemic species $(r=0.781, p<0.01)$ (Table 4).

Table 4. Spearman's rank correlations for species richness of eight plant groups.

\begin{tabular}{|c|c|c|c|c|c|c|c|c|}
\hline & Pteridophytes & Gymnosperms & Angiosperms & $\begin{array}{c}\text { Vascular } \\
\text { plants }\end{array}$ & $\begin{array}{c}\text { Woody } \\
\text { plants }\end{array}$ & $\begin{array}{c}\text { Herbaceous } \\
\text { plants }\end{array}$ & $\begin{array}{c}\text { Chinese } \\
\text { endemic } \\
\text { species }\end{array}$ & $\begin{array}{c}\text { Rare and } \\
\text { endangered } \\
\text { plants }\end{array}$ \\
\hline Pteridophytes & 1.000 & & & & & & & \\
\hline Gymnosperms & $0.593^{* *}$ & 1.000 & & & & & & \\
\hline Angiosperms & $0.775^{* *}$ & $0.815^{* *}$ & 1.000 & & & & & \\
\hline $\begin{array}{c}\text { Vascular } \\
\text { plants }\end{array}$ & $0.793^{* *}$ & $0.818^{* *}$ & $0.996^{* *}$ & 1.000 & & & & \\
\hline $\begin{array}{c}\text { Woody plants } \\
\text { fod }\end{array}$ & $0.554^{* *}$ & $0.501^{*}$ & $0.618^{* *}$ & $0.626^{* *}$ & 1.000 & & & \\
\hline $\begin{array}{c}\text { Herbaceous } \\
\text { plants }\end{array}$ & $0.734^{* *}$ & $0.776^{* *}$ & $0.925^{* *}$ & $0.921^{* *}$ & $0.425^{*}$ & 1.000 & & 1.000 \\
\hline $\begin{array}{c}\text { Chinese } \\
\text { endemic } \\
\text { species }\end{array}$ & $0.612^{* *}$ & $0.875^{* *}$ & $0.849^{* *}$ & $0.842^{* *}$ & $0.637^{* *}$ & $0.786^{* *}$ & \\
\hline $\begin{array}{c}\text { Rare and } \\
\text { endangered } \\
\text { plants }\end{array}$ & $0.601^{* *}$ & $0.768^{* *}$ & $0.732^{* *}$ & $0.742^{* *}$ & $0.473^{*}$ & $0.668^{* *}$ & $0.781^{* *}$ & 1.000 \\
\hline
\end{tabular}

*Correlation is significant at the 0.05 level. ** Correlation is significant at the 0.01 level. 


\section{Discussion}

Our study found that area, mean annual temperature, and mean annual precipitation were the factors determining species richness in temperate nature reserves. Species richness of all the groups were strongly associated with the area of nature reserves in a temperate region, which is consistent with the results of Zhang et al. [12] and Novaglio et al. [13]. Larger areas encompass more diverse habitats [11] and thus promote higher diversity. We also found that nature reserve area was the most dominant factor affecting species richness in the studied nature reserves across the temperate region of China (Shandong Province). These findings indicate that temperature and precipitation were similar across the temperate region, and the area of the nature reserves was sufficient to mask the effect of climatic variation between the studied nature reserves. Besides the area, we found that temperature and precipitation were two additional main climatic factors constraining species richness of the eight studied groups, which is consistent with previous analyses of the richness of vascular plants [6], pteridophytes [9-10], seed plants [9-10], woody plants [8], and herbaceous plants [28] in different parts of the world. Wang et al. [7] found that mean temperature of the coldest quarter was the best predictor of woody species richness in China. The difference in the results between our study and those of Wang et al. [7] was probably because of two factors: their study excluded exotic species and was conducted at a national scale based on a grid of $50 \times 50 \mathrm{~km}$, while our study included exotic species and was conducted in the temperate region of Shandong Province using the areas of nature reserves as a scale.

In recent decades, the study of endemism and its distribution pattern have caused widespread concern among ecologists as global biodiversity conservation research deepened [29-31]. Our results demonstrated that mean annual precipitation was positively correlated with Chinese endemic species. These results were consistent with those of Huang and Ma [26], who reported that precipitation was an important predictor of the endemic plant species richness in China. Our study also found that the multiple regression model explained $82.1 \%$ of rare and endangered plants. Therefore, the model better explained the variation in species richness of rare and endangered plants. The area of natural reserves was the main factor for effective protection of rare and endangered plants in the studied nature reserves, which was consistent with MacArthur and Wilson's Theory of Island Biogeography: the extinction rate of biological species depends on the size of the habitat area - the smaller area, the higher the extinction rate [32].

Diversity distribution and patterns within taxonomic units are related to various factors, including area, latitude, precipitation, and temperature [12, 15, 33-34]. Storch and Šizling [34] proposed that patterns of species richness are invariant across taxonomic units, while others have suggested that different taxonomic groups have different activation energies $[12,15,33]$. Our results suggest that the relationships between species richness and area, temperature, and precipitation were consistent in the eight different plant groups in the temperate region of China (Shandong Province), and the relationships between species richness and temperature and precipitation were consistent in the five groups across China. Similar findings were reported in previous studies of vascular plants for nature reserves on a national scale in China [6], and woody and herbaceous plant species richness in Great Britain [28].

Patterns of species richness are scale-dependent [16]. $\mathrm{Xu}$ et al. [5] in their study on vascular plant and mammal species from 2,376 counties across China found that the determinants of species richness patterns varied among regions. In our study, the mean annual precipitation and species richness were positively correlated at the two spatial scales (temperate region and national scale). In contrast, the plant richness-mean annual temperature relationships between the temperate region and the national scale were not consistent. We found that the mean annual temperature was negatively correlated with species richness in the temperate region, while positively correlated with species richness on a national scale. Zhao and Fang [6] suggested that all major taxonomic groups of vascular plants were positively correlated with mean annual temperature on a national scale in China. More significantly, our results have extended the relationship between temperature and vascular plants to rare and endangered plants. This disparity in the correlation between the two spatial scales might be because of the different scale and the particularity of nature reserves in the temperate region of Shandong Province.

\section{Conclusions}

Our results suggest that the nature reserve area, precipitation, and temperature are the factors that explain the variation of the eight plant groups in the temperate nature reserves of Shandong Province. The relationship between species richness and the determinants of variation are consistent in different groups at the two spatial scales. The plant richness-precipitation relationship is consistent at the two spatial scales, while the plant richness-temperature relationship is different between the two spatial scales. Plant species richness is negatively correlated with mean annual temperature in the temperate region, and positively correlated with mean annual precipitation on a national scale. The results of this study suggest that the relationship between the main explanatory factors and plant species richness are consistent in the studied groups and vary with spatial scale.

\section{Acknowledgements}

We would like to thank the Management Offices of Mount Yangtian and Mount Daqing Nature Reserves for providing their comprehensive reports. We express our gratitude to the Shandong Forestry Survey and Design 
Institute for providing the species checklists of 20 nature reserves. This study was supported by the Fundamental Research Funds of Shandong University (No. 2015JC023) and the National Natural Science Foundation of China (No. 31200426).

The authors Xiuhua Zhang, Hui Wang contributed equally to this work.

\section{References}

1. GASTON K.J. Global patterns in biodiversity. Nature, $\mathbf{4 0 5}$, $220,2000$.

2. KERKHOFF A.J., MORIARTY P.E., WEISER M.D. The latitudinal species richness gradient in New World woody angiosperms is consistent with the tropical conservatism hypothesis. PNAS, 111 (22), 8125, 2014.

3. DAVIES R.G., ORME C.D.L., STORCH D., OLSON V.A., THOMAS G.H., ROSS S.G., DING T., RASMUSSEN P.C., BENNETT P.M., OWENS P.F., BLACKBURN T.M., GASTON K.J. Topography, energy and the global distribution of bird species richness. Proceedings of the Royal Society B-Biological Sciences, 274 (1614), 1189, 2007.

4. QIAN H. Effects of historical and contemporary factors on global patterns in avian species richness. Journal of Biogeography, 35 (8), 1362, 2008.

5. XU H.G., CAO M.C., WU Y., CAI L., CAO Y., WU J., LEI J.C., LE Z.F., DING H., CUI P. Disentangling the determinants of species richness of vascular plants and mammals from national to regional scales. Scientific Reports, 6 (4), 241, 2016.

6. ZHAO S.Q., FANG J.Y. Patterns of species richness of vascular plants in China's nature reserves. Diversity and Distributions, 12, 364, 2006.

7. WANG Z.H., FANG J.Y., TANG Z.Y., LIN X. Patterns, determinants and models of woody plant diversity in China. Proceedings of the Royal Society B: Biological Sciences, 278 (1715), 2122, 2011

8. QIAN H. Environmental determinants of woody plant diversity at a regional scale in China. PLOS ONE, 8 (9), e75832, 2013.

9. KREFT H., JETZ W., MUTKE J., BARTHLOTT W. Contrasting environmental and regional effects on global pteridophyte and seed plant diversity. Ecography, 33 (2), 408, 2010.

10. CHEN S.B., JIANG G.M., OUYANG Z.Y., XU W.H., XIAO Y. Relative importance of water, energy, and heterogeneity in determining regional pteridophyte and seed plant richness in China. Journal of Systematics and Evolution, 49 (2), 95, 2011.

11. SHEN G.C., YU M.J., HU X.S., MI X.C., REN H.B., SUN I.F., MA K.P. Species-area relationships explained by the joint effects of dispersal limitation and habitat heterogeneity. Ecology, 90 (11), 3033, 2009.

12. ZHANG Q., WANG Z.Q., JI M.F., FAN Z.X., DENG J.M. Patterns of species richness in relation to temperature, taxonomy and spatial scale in eastern China. Acta Oecologica, 37 (4), 307, 2011.

13. NOVAGLIO C., FERRETTI F., SMITH A.D.M., FRUSHER S. Species-area relationships as indicators of human impacts on demersal fish communities. Diversity and Distributions, 22 (11), 1186, 2016.

14. SCHNEIDER D.C. The rise of the concept of scale in ecology. Bioscience, 51 (7), 545, 2001.
15. WANG Z.H, BROWN J.H., TANG Z.Y., FANG J.Y. Temperature dependence, spatial scale, and tree species diversity in eastern Asia and North America. Proceeding of the National Academy of Sciences, 106 (32), 13388, 2009.

16. MCGILL B.J. Matters of scale. Science, 328, 575, 2010.

17. CHEN X.C., WANG R.Q., CAO Q.Q., ZHANG H.J., GE X.L., LIU J. The Relationship between the Distribution of Invasive Plant Alternanthera philoxeroides and Soil Properties is Scale-Dependent. Polish J. of Environ. Stud, 24 (5), 1931, 2015.

18. QIAN H. Environment-richness relationships for mammals, birds, reptiles, and amphibians at global and regional scales. Ecological Research, 25 (3), 629, 2010.

19. DAVIES R.G., IRLICH U.M., CHOWN S.L., GASTON K.J. Ambient, productive and wind energy, and ocean extent predict global species richness of procellariiform seabirds. Global Ecology and Biogeography, 19 (1), 98, 2010.

20. KOPEĆ D., HALLADIN-DĄBROWSKA A., ZAJĄC I. Flora Dynamics in a Strictly Protected Nature Reserve. Polish J. of Environ. Stud, 20 (1), 107, 2011.

21. FAN S.J., HU Z.X. Flora of Laoshan Mountain. Science Press: Beijing, China, 1, 2003 [In Chinese].

22. WANG X.H., LI C.R. Biodiversity of Mount Tai. Intellectual Property Press: Beijing, China, 277, 2012 [In Chinese].

23. ZHANG X.J., ZHANG W.D., LI F.Z. Flora of Mount Tai. Shandong Science and Technology Press: Jinan, China, pp. 1-636, 2012 [In Chinese].

24. CHEN H.B., ZHENG Y.J., LI F.Z. Flora of Shandong. Qingdao Press: Qingdao, China, 1, 1990, 1997 [In Chinese].

25. LI F.Z., ZHAO Z.T., FAN S.J. Shandong Plant Essence. Science Press: Beijing, China, 1, 2004 [In Chinese].

26. HUANG J.H, MA K.P. The diversity and geographic distribution of Chinese endemic seed plant. Higher Education Press: Beijing, China, 1, 2014 [In Chinese].

27. BINI L.M., DINIZ-FILHO J.A.F., RANGEL T.F.L.V.B., AKRE T.S.B., ALBALADEJO R.G., ALBUQUERQUE F.S., APARICIO A., ARAÚJO M., BASELGA A., BECK J., BELLOCQ M.I., BÖHNING-GAESE K., BORGES P.A.V., CASTRO-PARGA I., CHEY V.K., CHOWN S.L., MARCO P.D., DOBKIN J.D.S., FERRER-CASTÁN D., FIELD R., FILLOY J., FLEISHMAN E., GÓMEZ J.F., HORTAL J., IVERSON J.B., KERR J.T., KISSLING W.D., KITCHING I.J., LEÓN-CORTÉS J.L., LOBO J.M., MONTOYA D., MORALES-CASTILLA I., MORENO J.C., OBERDORFF T., OLALLA-TÁRRAGA M.Á., PAUSAS J.G., QIAN H., RAHBEK C., RODRÍGUEZ M.Á., RUEDA M., RUGGIERO Á., SACKMANN P., SANDERS N.J., TERRIBILE L.C., VETAAS O.R., HAWKINS B.A. Coefficient shifts in geographical ecology: an empirical evaluation of spatial and non-spatial regression. Ecography, 32, (32), 193, 2009.

28. ALBUQUERQUE F.S., OLALLA-TÁRRAGA M.Á., MONTOYA D., RODRIGUEZ M.Á. Environmental determinants of woody and herb plant species richness patterns in Great Britain. Ecoscience, 18 (4), 394, 2011.

29. MYERS N., MITTERMEIER R.A., MITTERMEIER C.G., FONSECA G.A.B., KENT J. Biodiversity hotspots for conservation priorities. Nature, 403 (6772), 853, 2000.

30. BROOKS T.M., MITTERMEIER R.A., FONSECA G.A.B., GERLACH J., HOFFMANN M., LAMOREUX J.F., MITTERMEIER C.G., PILGRIM J.D., RODRIGUES A.S.L. Global biodiversity conservation priorities. Science, 313 (5783), 58, 2006.

31. LAMOREUX J.F., MORRISON J.C., RICKETTS T.H., OLSON D.M., DINERSTEIN E., MCKNIGHT M.W., SHUGART H.H. Global tests of biodiversity concordance 
and the importance of endemism. Nature, 440 (7081), 212, 2006.

32. MACARTHUR R.H., WILSON E.O. The Theory of Island Biogeography. Princeton University Press: Princeton, NJ, $522,1967$.

33. HAWKIN B.A., ALBUQUERQUE F.S., ARAUUJO M.B., BECK J., BINI L.M., CABRE-SAÑUDO F.J., CASTROPARGA I., DINIZ-FILHO J.A.F., FERRER-CASTÁN D., FIELD R., GÓMEZ J.F., HORTAL J., KERR J.T.,
KITCHING I.J., LEÓN-CORTÉS J.L., LOBO J.M., MONTOYA D., MORENO J.C., OLALLA-TÁRRAGA M.Á., PAUSAS J.G., QIAN H., RAHBEK C., RODRÍGUEZ M.Á., SANDERS N.J., WILLIAMS P. A global evaluation of metabolic theory as an explanation for terrestrial species richness gradients. Ecology, 88 (8), 1877, 2007.

34. STORCH D., ŠIZLING A.L. The concept of taxon invariance in ecology: do diversity patterns vary with changes in taxonomic resolution? Folia Geobotanica, 43 (3), 329, 2008. 